\title{
A Review of Trends and Crime Patterns of Arson Offences in India: 2009-2018
}

Fernandes Glorita Savia ( $\sim$ fernandesglorita10@gmail.com )

Karnatak University, Dharwad

C. F. Mulimani

Karnatak Science College, Dharwad

\section{Research Article}

Keywords: Arson, Crime trends, Crime patterns, Criminological research, Criminology

Posted Date: June 8th, 2021

DOI: https://doi.org/10.21203/rs.3.rs-602057/v1

License: (c) (1) This work is licensed under a Creative Commons Attribution 4.0 International License. Read Full License 


\section{Abstract}

Crime statistics provide innate knowledge on different types of crimes, their jurisdictions, current status and future predictive trends in society. This research paper is based on the review of data available in the national open access publication of crime data in the country. It focuses on arson offences in India for the last decade from 2009 to 2018 . It is important to study national crime statistics to enhance policing and criminological studies in different trends encountered through research. Explaining the trends of a crime in a country can help in establishing better policies, reporting systems, investigative methods and ultimately, a better criminal justice system. While Criminology studies have been generally focused on behavior, causes, etc. associated with violent crimes like offences against the body, violence against women, offences against children; this paper is aimed at discussing trends with respect to arson, a lesser known offence in our country.

\section{Introduction}

Criminology and Forensic science are important parts of the legal framework. They are needed to understand criminal behaviour, crime and provide scientific evidence for investigations. While fire and arson crime and research are prevalent globally, not much research exists on this area in the Indian context [17]. The Indian Penal Code (IPC) provides the legal framework for crimes and punishment detailed in various chapters according to classification of offences in India. Arson offences were originally classed under violent crimes, however, this was amended to offences against property and public safety later. Currently, it is also classed under "miscellaneous IPC crimes" corresponding to the timely changes in social dynamics of the country $[1,3,13]$.

Crime studies are an important part of policy making. It is important to study trends and patterns from crime statistics for predictive policing and analysing and addressing future concerns proactively $[2,16]$. It can be used by various people like law enforcement officials, researchers, criminal justice professionals and politicians to gain insights into crime status in the community and safety aspects of the public [14]. When required, it can lead to amendments of existing laws for better safety and security reasons.

Cognizable crimes in India are registered under two procedures: Indian Penal Code (IPC) and Special \& Local Laws (SLL) in the country. In India, arson is registered as a cognizable offence under Sections 435, 436 \& 438 of the Indian Penal Code (IPC). While in the USA, the Uniform Crime Reporting (UCR) system is used by the FBI for collection of crime statistical data; in a similar manner, the National Crime Records Bureau uses a nationalised software entry system for collation of crime data from states and union territories in India [4,15]. Crime in India is a timely publication from the NCRB to provide information to the general public, researchers, professionals and policy makers, a comprehensive approach to public safety in relation to crimes in society $[1,17]$. It provides key statistics in terms of offences against women and 
children, offences against the body, crimes against Scheduled Castes and Scheduled Tribes, etc. This data helps in establishing a crime chart for the country and its implications on the future trends [4-13].

Purpose/Aim of this study: This research paper is a review study of trends in arson crimes in India. The review has been conducted to assess crime statistics over the years in regards to Arson prevalence in the country. It provides information at a glance with respect to trends in arson crimes in India between 2009 and 2018; thus providing awareness to the readers. The paper focuses on the scope for further research on this topic for determination of future likelihood patterns of arson crimes in the state and the need to study the causes and motives for arson crimes in the Indian context, thereby developing a profile of offences and offenders across the country.

\section{Materials And Methods}

Sampling and Sampling technique: The study has collected data through Purposive Sampling technique for data collection using Non-Probability Sampling. The sampling was carried out for data available in a particular time frame i.e. Ten year duration from 2009 to 2018 . There is no primary data in this paper as all data was collected from existing literature review.

Data collection: Secondary data was collected from the annual published crime reports of the National Crime Records Bureau (NCRB), New Delhi, India. The facts and numerical data regarding arson offences solely, were gathered from online and offline publications of the book titled "Crime in India" for the years from 2009 to 2018 [4-13]. Each book is published annually covering different data of crimes in India, after processing the data collected by the individual State Crime Record Bureau (SCRB). Each report is based on primary data collected for a calendar year i.e. 1st January to 31st December. The data is received in prescribed format as given by NCRB through software entry by the 36 States/Union Territories.

First level data entry is done by concerned police officials in stations at the city or district level. Second level data validation and compilation in prescribed format is done by the State Crime Record Bureau or Criminal Investigation Department (CID). This data undergoes scrutiny for inconsistencies and discrepancies by the National Crime Records Bureau, which ultimately publishes a report on the trends of crime statistics in the country.

Legal disclaimer: This work is solely the original interpretation of the authors based on recorded data from the National Crime Records Bureau. It does not reflect any opinions or theories of the NCRB or SCRB, or its personnel in any manner. 


\section{Observations And Analysis}

Arson crime incidents are reported annually and registered under cognizable offences under the Indian Penal Code, 1860. Crime incidence is the number of First information Reports (FIR's) registered. Through the years from 1995 to 2008, arson crimes have shown a mixed trend which decreases towards the late 2000's as shown in Figure 1. The highest arson crimes were recorded in the year 1998 with 12913 offences being registered across the country. While the trend is exponentially directed, it can be seen that lowest arson offences were recorded in the year 2005 with 8451 offences.

In the next illustration seen as Figure 2, it can again be seen that there is a mixed trend in arson offences registered from 2009 to 2018 with sharp increases in the years 2012 and 2016 with 11836 and 11196 cases registered, respectively. Apart from these two years, the number of offences registered annually ranges between 8500 to 9800 cases, with the lowest number of cases being recorded in 2010 with 8508 incidents.

The break-up of arson offences registered yearly by the 29 states and 7 union territories of India has been compiled as seen in Table 1. The number of arson crimes are as per data recorded by NCRB based on data provided by the respective States/Union Territories. From the data, it can be observed that on an average, Maharashtra records the largest number of offences of arson as violent crimes under IPC. These figures can be due to large forest cover in the area and industrial economy of the state. Amongst the Union Territories, it can be observed that Delhi shows an increase in arson incidents every year and has the highest numbers amongst the others. An overall decreasing trend in arson crimes has been observed in the states of Andhra Pradesh, Bihar, Jharkhand, Manipur, Punjab and Rajasthan. An overall mixed pattern over the years has been observed in states of Arunachal Pradesh, Assam, Chattisgarh, Goa, Gujarat, Himachal Pradesh, Jammu and Kashmir, Karnataka, Kerala, Madhya Pradesh, Meghalaya, Mizoram, Nagaland, Telangana, Tamil Nadu and Uttarakhand. Overall increasing trend is noticed amongst Haryana, Maharashtra, Odisha, Sikkim, Tripura, Uttar Pradesh and West Bengal.

Table 1: Number of arson incidents reported as violent crimes state-wise and year-wise in India from 2009 to 2018. 


\begin{tabular}{|c|c|c|c|c|c|c|c|c|c|c|}
\hline \multicolumn{11}{|c|}{ Number of incidence of Arson Crimes (Sec. 435, 436 \& 438 IPC) } \\
\hline STATE/UT & 2009 & 2010 & 2011 & 2012 & 2013 & 2014 & 2015 & 2016 & 2017 & 2018 \\
\hline Andhra Pradesh & 1039 & 925 & 1021 & 980 & 932 & 450 & 516 & 519 & 426 & 468 \\
\hline Arunachal Pradesh & 28 & 28 & 34 & 33 & 23 & 39 & 32 & 31 & 35 & 26 \\
\hline Assam & 476 & 437 & 506 & 2830 & 793 & 743 & 826 & 664 & 571 & 615 \\
\hline Bihar & 685 & 660 & 705 & 799 & 660 & 517 & 448 & 472 & 375 & 399 \\
\hline Chattisgarh & 335 & 319 & 289 & 330 & 328 & 297 & 382 & 341 & 336 & 348 \\
\hline Goa & 24 & 23 & 24 & 34 & 39 & 41 & 22 & 17 & 34 & 19 \\
\hline Gujarat & 240 & 260 & 263 & 282 & 304 & 217 & 273 & 242 & 200 & 278 \\
\hline Haryana & 153 & 221 & 166 & 191 & 189 & 203 & 234 & 1070 & 388 & 275 \\
\hline Himachal Pradesh & 124 & 127 & 110 & 131 & 138 & 97 & 84 & 94 & 99 & 104 \\
\hline Jammu and Kashmir & 217 & 224 & 205 & 190 & 221 & 159 & 148 & 268 & 183 & 192 \\
\hline Jharkhand & 203 & 185 & 138 & 136 & 185 & 94 & 100 & 143 & 92 & 167 \\
\hline Karnataka & 293 & 286 & 231 & 416 & 332 & 484 & 464 & 471 & 409 & 338 \\
\hline Kerala & 503 & 374 & 450 & 568 & 479 & 453 & 562 & 554 & 405 & 341 \\
\hline Madhya Pradesh & 741 & 748 & 784 & 814 & 671 & 865 & 834 & 800 & 833 & 721 \\
\hline Maharashtra & 1105 & 1229 & 1255 & 1246 & 1197 & 1180 & 1299 & 1338 & 1184 & 1312 \\
\hline Manipur & 81 & 86 & 99 & 74 & 38 & 43 & 75 & 59 & 40 & 27 \\
\hline Meghalaya & 54 & 52 & 34 & 61 & 127 & 38 & 34 & 29 & 71 & 59 \\
\hline Mizor & 24 & 15 & 19 & 12 & 27 & 22 & 17 & 27 & 18 & 14 \\
\hline Nagaland & 4 & 1 & 2 & 7 & 9 & 7 & 7 & 3 & 6 & 5 \\
\hline Odisha & 413 & 430 & 423 & 469 & 416 & 477 & 505 & 524 & 604 & 555 \\
\hline Punjab & 101 & 101 & 83 & 74 & 65 & 63 & 80 & 78 & 86 & 80 \\
\hline Rajasthan & 556 & 478 & 473 & 475 & 484 & 523 & 472 & 370 & 477 & 438 \\
\hline Sikkim & 9 & 7 & 4 & 20 & 19 & 40 & 4 & 17 & 8 & 13 \\
\hline Tamil Nadu & 580 & 636 & 706 & 726 & 645 & 675 & 677 & 513 & 402 & 434 \\
\hline Telangana* & NA & NA & NA & NA & NA & 482 & 436 & 451 & 430 & 512 \\
\hline Tripura & 62 & 51 & 58 & 59 & 83 & 59 & 25 & 34 & 32 & 119 \\
\hline Uttar Pradesh & 254 & 170 & 477 & 327 & 291 & 250 & 396 & 1325 & 604 & 726 \\
\hline Uttarakhand & 17 & 17 & 17 & 17 & 17 & 8 & 9 & 9 & 16 & 10 \\
\hline West Bengal & 344 & 331 & 413 & 396 & 495 & 544 & 503 & 523 & 640 & 511 \\
\hline Total (States) & 8665 & $\overline{8421}$ & 8989 & 11697 & 9207 & 9070 & 9464 & 10986 & 9004 & 9106 \\
\hline and Nicobar & & & & & & & & & & \\
\hline Islands & 12 & 12 & 6 & 4 & 2 & 5 & 4 & 9 & 4 & 4 \\
\hline Chandigarh & 4 & 9 & 4 & 9 & 8 & 13 & 7 & 8 & 13 & 14 \\
\hline Dadra and Nagar Haveli & 5 & 2 & 5 & 12 & 18 & 5 & 2 & 2 & 2 & 1 \\
\hline Daman and Diu & 3 & 0 & 0 & 11 & 8 & 0 & 4 & 2 & 6 & 1 \\
\hline Delhi & 34 & 52 & 42 & 79 & 97 & 190 & 224 & 183 & 148 & 126 \\
\hline Lakshadweep & 2 & 2 & 3 & 3 & 1 & 5 & 5 & 5 & 5 & 0 \\
\hline Puducherry & 11 & 10 & 10 & 21 & 16 & 1 & 0 & 1 & 4 & 0 \\
\hline Tota & 71 & 87 & 70 & 139 & 150 & 219 & 246 & 210 & 182 & 146 \\
\hline
\end{tabular}

\section{Total number of incidents} (States+UT's)

873685089059118369357928997101119691869252

* Note:Telangana was incorporated into a State and formed the 29th state in India on 2nd June 2014. Hence, data collection before 2014 reflects Telangana as part of the State of Andhra Pradesh. 
The number of arson crimes booked under sections 435-438 IPC shows a mixed trend for the years from 2009 to 2018. The number of arson offences to the total number of IPC crimes in the country has been shown in Table 2. From this, it can be observed that arson offences make up 0.3 to 0.4 percent of total IPC crimes yearly. The rate of arson crime has been recorded in the range of 0.7 to 0.9 annually (NCRB). Crime rate is calculated as the Crime Incidence per one lakh population. The population estimation is obtained from the Registrar General of India done annually and based on the 2001 population census.

Table 2: Total number of arson incidents recorded under Sections of IPC and the total number of IPC cases received annually from 2009 to 2018.

\begin{tabular}{|r|r|r|}
\hline \multicolumn{4}{|c|}{$\begin{array}{c}\text { Arson cases registered to the Total IPC crimes in a year } \\
\text { Year }\end{array}$} & $\begin{array}{c}\text { Number of cases booked under Sections for arson } \\
\text { (Sec.435-438 IPC) }\end{array}$ & $\begin{array}{c}\text { Total number of crimes } \\
\text { registered under IPC }\end{array}$ \\
\hline 2009 & 8736 & 230500 \\
\hline 2010 & 8508 & 241986 \\
\hline 2011 & 9064 & 256329 \\
\hline 2012 & 11836 & 275165 \\
\hline 2013 & 9357 & 300357 \\
\hline 2014 & 9289 & 330754 \\
\hline 2015 & 9710 & 335901 \\
\hline 2016 & 11196 & 429299 \\
\hline 2017 & 9186 & 426825 \\
\hline 2018 & 9252 & 428134 \\
\hline
\end{tabular}

Crimes against public safety record both riots and arson offences across the country. The trend seen in the case of "crimes against public safety" is a steady increase from 2009 to 2015 with the exception of 2012, wherein an unusual high was recorded as seen in Figure 3. The data for crimes against public safety was reorganized after the 2015 publication to include other elements and arson offences were further grouped into miscellaneous IPC offences and offences against public/government property reported by other institutions like Government Railways, Naxalite and insurgent attacks, Terrorist activity, etc. The upward linear trendline has been displayed in Figure $\mathbf{3}$ defined by equation $2378 * x+73590$ and having $\mathrm{R}^{2}$ value $=0.789$. The percentage of crimes against public order comprises between 2.9 to 3.6 percent of total IPC crimes registered annually as seen in Table 3. While the state of Kerala showed the highest rates of such incidents for five years, Lakshadweep islands recorded the highest offences for two years. Kerala recorded the highest rates of crimes against public order for the years 2010, 2011, 2012, 2013 and 2015 with crime rates of 26, 33.6, 33, 30 and 19.6 respectively. Lakshadweep on the other hand showed crime rates of 64.8 and 20.3 which were highest for the years 2009 and 2014 .

Table 3: Proportion of crimes against public safety to total IPC crimes recorded from 2009 to 2015. The state with the highest number of such crimes and its respective crime rate has also been listed. 


\begin{tabular}{|c|c|c|c|}
\hline Year & $\begin{array}{c}\text { Percentage of crimes against public } \\
\text { safety to total IPC crimes }\end{array}$ & $\begin{array}{c}\text { Highest crime rate } \\
\text { (riots + arson) }\end{array}$ & $\begin{array}{c}\text { State with highest } \\
\text { crime rate }\end{array}$ \\
\hline 2009 & 3.4 & 64.8 & Lakshadweep \\
\hline 2010 & 3.4 & 26 & Kerala \\
\hline 2011 & 3.3 & 33.6 & Kerala \\
\hline 2012 & 3.6 & 33 & Kerala \\
\hline 2013 & 3.1 & 30 & Kerala \\
\hline 2014 & 3 & 20.3 & Lakshadweep \\
\hline 2015 & 2.9 & 19.6 & Kerala \\
\hline
\end{tabular}

In India, there is a typical category system wherein there exist the general quota (GN), Other Backward Classes (OBC), Scheduled Caste (SC) and Scheduled Tribe (ST), etc. General IPC offences are specially categorised for the SC and ST in the country to protect their interests. Hence, the trends of arson offences against these categories has also been analysed. The trends in arson offences against the Scheduled Castes (SC) and Scheduled Tribes (ST) for the years from 2009 to 2018 show a mixed trendline with offences crossing the 200 mark for against Scheduled Caste in the years 2012, 2014 and 2015 as seen in Figure 4(a). While the number of offences against Scheduled Caste outnumber those against Scheduled Tribes, it can be seen that there was a sharp increase in the number of offences registered for years 2013 to 2015, followed by a drastic decline in numbers noticed from 2016 to 2018 as seen in Figure 4(b). From 2016 onward, it can be observed that there is a decrease in arson crimes against both the categories.

It can also be observed that a comparison of yearly trends in percentage of arson crimes to other IPC offences registered against Scheduled Caste and Scheduled Tribes is seen as a downward trend as indicated in Table 4. This indicates that while other types of crimes are increasing, the number of arson offences against these categories is decreasing, which is a good trend for the future.

Table 4: Percentage of Arson crimes against Scheduled Castes (SC) and Scheduled Tribes (ST) to total IPC crimes against SC/ST between 2009 and 2018.

\begin{tabular}{|c|c|c|}
\hline \multicolumn{3}{|c|}{ Percentage of Arson crimes to total crimes recorded annually against SC/ST } \\
\hline Year & Incidents reported against SC & Incidents reported against ST \\
\hline 2009 & 0.58 & 0.53 \\
\hline 2010 & 0.46 & 0.66 \\
\hline 2011 & 0.50 & 0.42 \\
\hline 2012 & 0.64 & 0.44 \\
\hline 2013 & 0.48 & 0.49 \\
\hline 2014 & 0.43 & 0.41 \\
\hline 2015 & 0.46 & 0.58 \\
\hline 2016 & 0.46 & 0.22 \\
\hline 2017 & 0.35 & 0.15 \\
\hline 2018 & 0.34 & 0.17 \\
\hline
\end{tabular}

From 2009 to 2015, it can be seen that the crime rate for arson offences ranges between 0.7 to 1 while the average arrest rate is 0.985 for the same duration as shown in Table 5 . Arrest rate is calculated as number of persons arrested per lakh population. The number of 
arrests per case ranges between 1.1 to 1.6 arrests. The number of persons arrested shows a mixed trend over the period.

Table 5: Number of persons arrested for arson crimes and crime rate versus arrest rate for arson incidents in the country from 2009 to 2015.

\begin{tabular}{|c|c|c|c|c|c|}
\hline \multicolumn{5}{|c|}{ Data of Crime rate and Arrest rate for IPC Arson crimes } \\
\hline Year & $\begin{array}{c}\text { Number of Persons } \\
\text { arrested for Arson }\end{array}$ & $\begin{array}{c}\text { Total number of } \\
\text { Persons arrested }\end{array}$ & $\begin{array}{c}\text { Crime } \\
\text { rate }\end{array}$ & $\begin{array}{c}\text { Arrest } \\
\text { rate }\end{array}$ & $\begin{array}{c}\text { Number of arrests } \\
\text { per case }\end{array}$ \\
\hline 2009 & 11486 & 2849025 & 0.7 & 1 & 1.3 \\
\hline 2010 & 10667 & 2947122 & 0.7 & 0.9 & 1.3 \\
\hline 2011 & 12380 & 3145845 & 0.7 & 1 & 1.4 \\
\hline 2012 & 12572 & 3270016 & 1 & 1 & 1.1 \\
\hline 2013 & 11699 & 3523577 & 0.8 & 1 & 1.3 \\
\hline 2014 & 14516 & 3790812 & 0.7 & 1.2 & 1.6 \\
\hline 2015 & 10661 & 3636596 & 0.8 & 0.8 & 1.1 \\
\hline
\end{tabular}

\section{Results And Discussion}

The paper reviewed annual crime statistics for a period of ten years from 2009 to 2018 with respect to arson crimes. The data obtained from the reports of the Crime Records Bureau were analysed for trends and patterns in arson offences across the country, in different states and groups of people.

The review paper found that arson offences showed a slight upward trend across the ten years studied from 2009 to 2018, if a linear trendline was plotted against the data. Cases recorded ranged from a maximum of 11836 cases in 2012 to a minimum of 8505 cases in 2010 . Overall, there was a general decline and mixed trendline in arson offences as violent crimes from 1995 to 2018 . This may be attributed to the fact that arson had been reclassified from violent crimes to offences against public safety and property. However, it was seen that offences were booked under Sections 435, 436 and 438 only of Indian Penal Code.

The rate of crime for arson was seen to be between 0.7 to 0.9 indicating that these offences comprise 0.3 to 0.4 percent of total IPC offences registered in the country on an annual basis. This showed that there are still considerable cases being registered every year and hence, need for action is necessary. It also stressed the need for more efficient investigation into these offences. While comparing riots and arson offences registered as crimes against public safety, it was seen that riots were considerably higher than arson offences.

Studies on trends in arson offences against Scheduled Castes showed a relatively constant number of offences from 2009 to 2018. The highest number of offences were seen in 2012. The number of cases 
registered showed a decreasing trend from 2016 to 2018, indicating that arson crimes are declining against the community. Studies on trends in arson offences against Scheduled Tribes showed a sharp decrease towards the latter half from 2016 to 2018; however the years from 2009 to 2013 showed about double the number of offences registered from 2016 to 2018. The lesser number of offences registered against the SC/ST community needs to be further investigated to determine if declining trends are due to actual reduction in offences or due to other factors.

\section{Conclusion}

This review paper was compiled with the objective to study patterns in arson crime statistics in the Indian scenario between 2009 and 2018. It can be noted that arson crimes show an overall mixed trend indicating that while number of offences may increase or decrease annually, this offence is still prevalent in society. Further research and study needs to be undertaken in this field especially in order to correlate the existing data for predictive policing and community safety engineering. Crime trend studies need further probe and deeper assessment to study the criminological traits associated with the offences and

thus, offer the opportunity for predictive policing improving the criminal justice system $[1,2]$. There is also a need to create awareness and reach the concerned authorities through this review paper, highlighting the need for better investigation and research methods in the field of forensic fire investigation [3].

\section{Declarations}

Declaration of Interest: This paper is the original work of the authors and has not been influenced inappropriately by any financial or personal relationships. The study does not have any conflict of interest and hence, no declarations of interest have been made.

\section{References}

1. Baumer, E. P., Vélez, M. B., \& Rosenfeld, R. 2018. Bringing Crime Trends Back into

Criminology: A Critical Assessment of the Literature and a Blueprint for Future Inquiry. Annual Review of Criminology, 1(1), 39-61.

doi:10.1146/annurev-criminol-032317-092339.

2. Gibbs, P. 2018, January 17. The benefits of data in criminal justice: Improving policing.

Sunlight Foundation. Retrieved from https://sunlightfoundation.com/2015/04/29/the-benefits-of-data-incriminal-justice-improving-policing/

3. Lauritsen, J. L., \& Cork, D. L. 2016. Modernizing crime statistics: Report 1 - Defining and classifying crime. National Academies Press. 
4. National Crime Records Bureau. 2009. Crime in India. National Crime Records Bureau

(Ministry of Home Affairs), Government of India, New Delhi. Retrieved from https://ncrb.gov.in

5. National Crime Records Bureau. 2010. Crime in India. National Crime Records Bureau

(Ministry of Home Affairs), Government of India, New Delhi. Retrieved from https://ncrb.gov.in

6. National Crime Records Bureau. 2011. Crime in India. National Crime Records Bureau

(Ministry of Home Affairs), Government of India, New Delhi. Retrieved from https://ncrb.gov.in

7. National Crime Records Bureau. 2012. Crime in India. National Crime Records Bureau

(Ministry of Home Affairs), Government of India, New Delhi. Retrieved from https://ncrb.gov.in

8. National Crime Records Bureau. 2013. Crime in India. National Crime Records Bureau

(Ministry of Home Affairs), Government of India, New Delhi. Retrieved from https://ncrb.gov.in

9. National Crime Records Bureau. 2014. Crime in India. National Crime Records Bureau

(Ministry of Home Affairs), Government of India, New Delhi. Retrieved from https://ncrb.gov.in

10. National Crime Records Bureau. 2015. Crime in India. National Crime Records Bureau

(Ministry of Home Affairs), Government of India, New Delhi. Retrieved from https://ncrb.gov.in

11. National Crime Records Bureau. 2016. Crime in India. National Crime Records Bureau

(Ministry of Home Affairs), Government of India, New Delhi. Retrieved from https://ncrb.gov.in

12. National Crime Records Bureau. 2017. Crime in India. National Crime Records Bureau

(Ministry of Home Affairs), Government of India, New Delhi. Retrieved from https://ncrb.gov.in

13. National Crime Records Bureau. 2018. Crime in India. National Crime Records Bureau

(Ministry of Home Affairs), Government of India, New Delhi. Retrieved from https://ncrb.gov.in

14. Rosenfeld, R., \& Weisburd, D. 2016. Explaining Recent Crime Trends: Introduction to the

Special Issue. Journal of Quantitative Criminology, 32(3), 329-334. doi:10.1007/s10940-016-9317-6

15. Uniform Crime Reporting (UCR) Program. 2018, September 10. Retrieved from

https://www.fbi.gov/services/cjis/ucr

Page 10/13 
16. Walden University. 2019, February 14. Why National Crime Statistics Are Important.

Retrieved from https://www.waldenu.edu/online-bachelors-programs/bs-in-criminal-justice/resource/whynational-crime-statistics-are-important

17. Why India needs timely crime data. 2019, September 24. Retrieved from

https://www.hindustantimes.com/analysis/why-india-needs-timely-crime-data/story-

J7JHV93ePXObR5gl70WexN.html

\section{Figures}

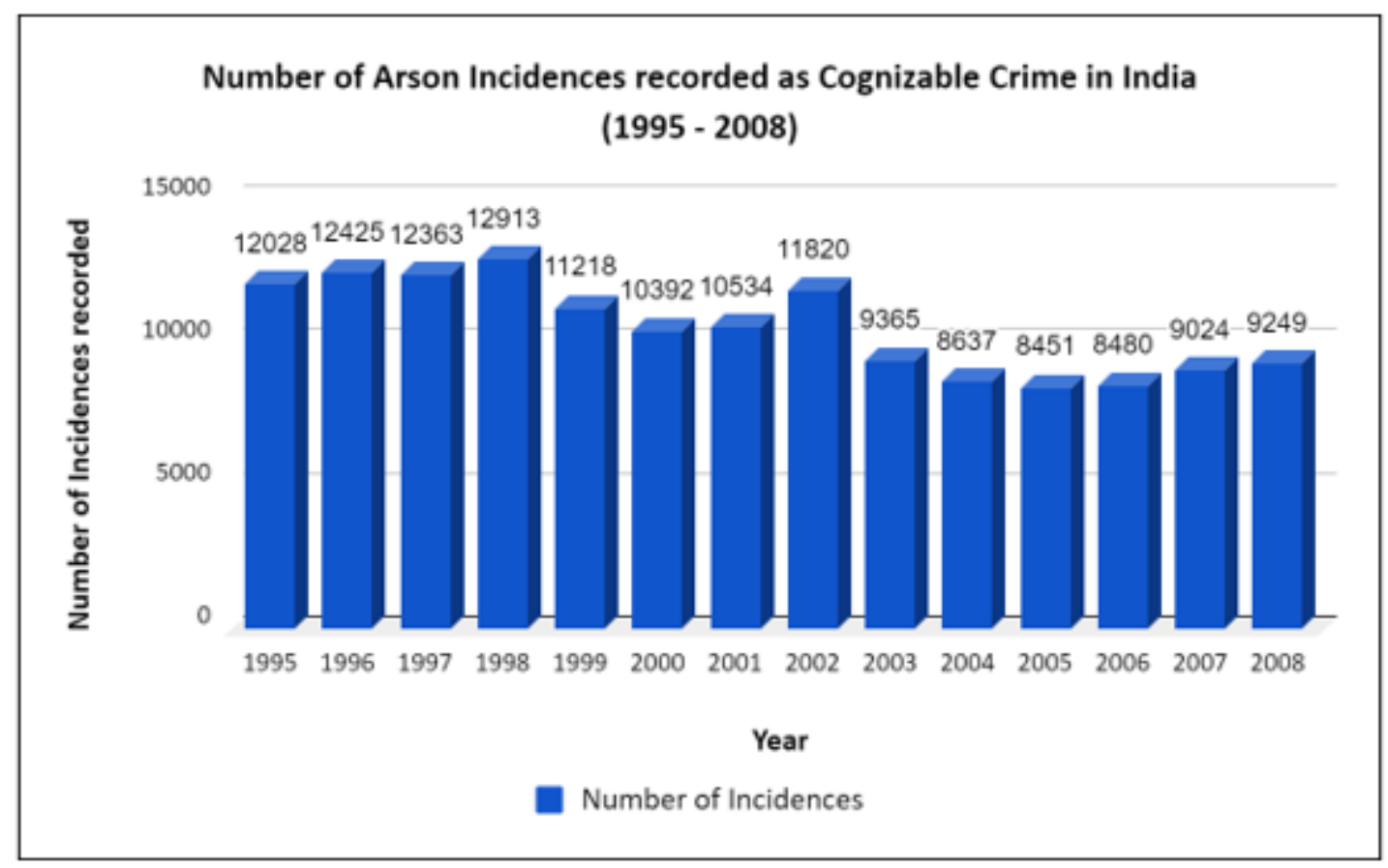

\section{Figure 1}

The number of arson incidents reported as cognizable crimes in India between 1995 and 2008. 




Figure 2

The number of arson incidents reported as cognizable crimes in India between 2009 and 2018.

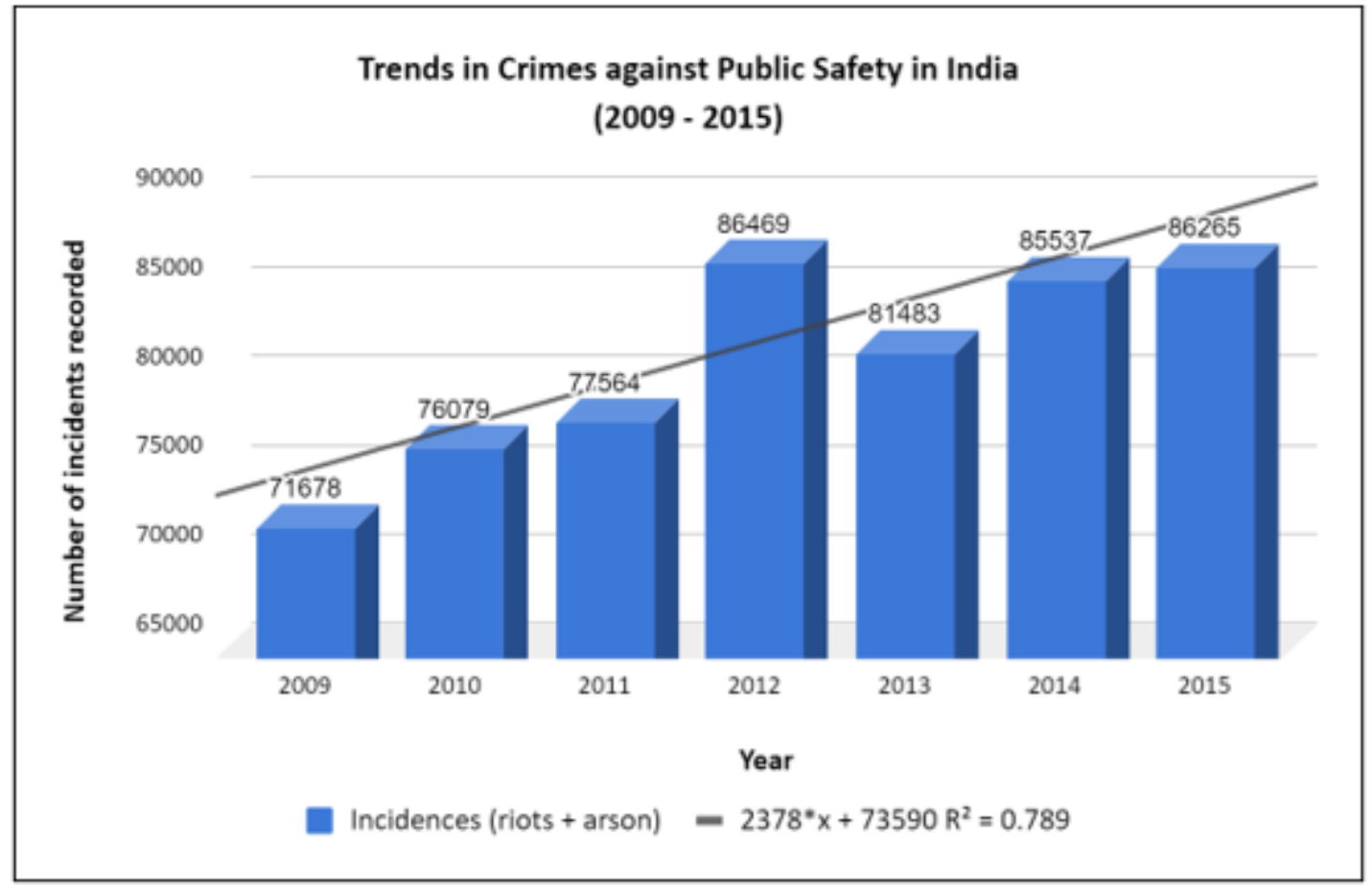

Figure 3

The Annual Trend in Crimes Against Public Safety comprising Riots and Arson cases across the country from 2009 to 2015. 

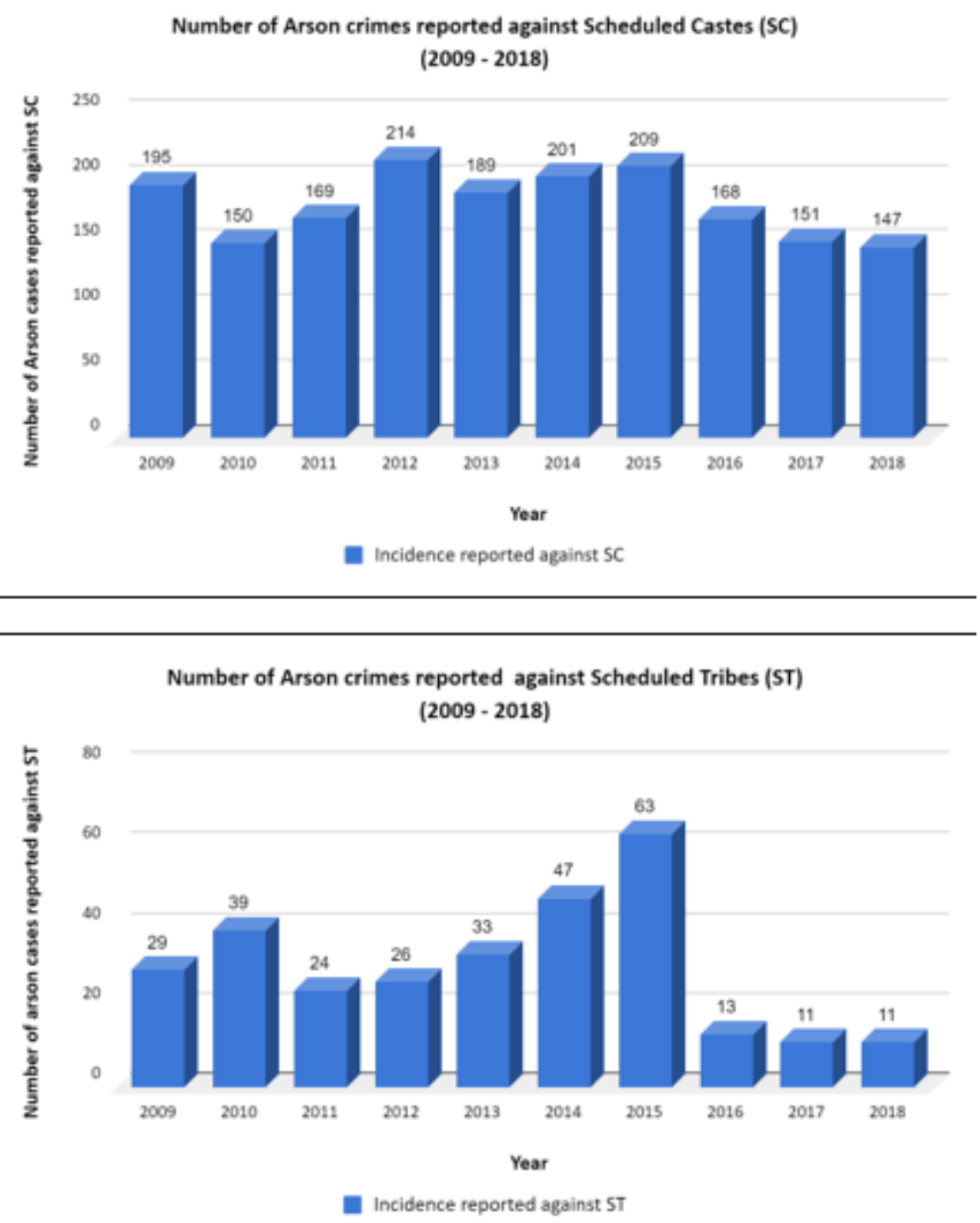

Figure 4

(a): The number of arson crimes recorded annually against the Scheduled Castes (SC) between 2009 and 2018. (b): The number of arson crimes recorded annually against the Scheduled Tribes (ST) between 2009 and 2018. 